\title{
Zucchini yellow mosaic virus Genomic Sequences from Papua New Guinea: Lack of Genetic Connectivity with Northern Australian or East Timorese Genomes, and New Recombination Findings
}

\author{
Solomon Maina, ${ }^{1,2,3}$ Martin J. Barbetti, ${ }^{1,2,3}$ Owain R. Edwards, ${ }^{3,4}$ David Minemba, ${ }^{1,5}$ Michael W. Areke, ${ }^{6}$ \\ and Roger A. C. Jones ${ }^{2,3,7, \dagger}$ \\ ${ }^{1}$ School of Agriculture and Environment, Faculty of Science, and ${ }^{2}$ UWA Institute of Agriculture, Faculty of Science, The Uni- \\ versity of Western Australia, Crawley, WA, Australia; ${ }^{3}$ Cooperative Research Centre for Plant Biosecurity, Canberra, Australian \\ Capital Territory, Australia; ${ }^{4}$ Commonwealth Scientific and Industrial Research Organisation Land and Water, Floreat Park, WA \\ 6014, Australia; ${ }^{5}$ The National Agricultural Research Institute, PO Box 4415, Lae, Morobe Province, Papua New Guinea; \\ ${ }^{6}$ National Agriculture Quarantine and Inspection Authority, PO Box 741, Port Moresby, National Capital District, Papua \\ New Guinea; and ${ }^{7}$ Department of Primary Industries and Regional Development, South Perth, WA, Australia
}

\begin{abstract}
Zucchini yellow mosaic virus (ZYMV) isolates were obtained in Papua New Guinea (PNG) from cucumber (Cucumis sativus) or pumpkin (Cucurbita spp.) plants showing mosaic symptoms growing at Kongop in the Mount Hagen District, Western Highlands Province, or Zage in the Goroka District, Eastern Highlands Province. The samples were blotted onto FTA cards, which were sent to Australia, where they were subjected to high-throughput sequencing. When the coding regions of the nine new ZYMV genomic sequences found were compared with those of 64 other ZYMV sequences from elsewhere, they grouped together, forming new minor phylogroup VII within ZYMV's major phylogroup A. Genetic connectivity was lacking between ZYMV genomic sequences from PNG and its neighboring countries, Australia and East Timor; the closest match between a PNG and any other genomic sequence was a 92.8\% nucleotide identity with a sequence in major phylogroup A's minor phylogroup VI from Japan. When the RDP5.2 recombination analysis program was used to compare $66 \mathrm{ZYMV}$ sequences, evidence was obtained of 30 firm recombination events involving 41 sequences, and all isolates from PNG were recombinants. There were 21 sequences

without recombination events in major phylogroup $\mathrm{A}$, whereas there were only 4 such sequences within major phylogroup B. ZYMV's P1, $\mathrm{Cl}$, N1a-Pro, P3, CP, and NIb regions contained the highest evidence of recombination breakpoints. Following removal of recombinant sequences, seven minor phylogroups were absent (I, III, IV, V, VI, VII, and VIII), leaving only minor phylogroups II and IX. By contrast, when a phylogenetic tree was constructed using recombinant sequences with their recombinationally derived tracts removed before analysis, five previous minor phylogroups remained unchanged within major phylogroup A (II, III, IV, V, and VII) while four formed two new merged phylogroups (I/VI and VIII/IX). Absence of genetic connectivity between PNG, Australian, and East Timorese ZYMV sequences, and the $92.8 \%$ nucleotide identity between a PNG sequence and the closest sequence from elsewhere, suggest that a single introduction may have occurred followed by subsequent evolution to adapt to the PNG environment. The need for enhanced biosecurity measures to protect against potentially damaging virus movements crossing the seas separating neighboring countries in this region of the world is discussed.
\end{abstract}

Present address of S. Maina: Grains Innovation Park, DEDJTR Horsham Centre, Horsham, VIC 3400, Australia.

${ }^{\dagger}$ Corresponding author: R. A. C. Jones. E-mail: roger.jones@uwa.edu.au

Funding: This study forms part of a Ph.D. research project by the first author at the University of Western Australia (UWA). The Cooperative Research Centre for Plant Biosecurity (PBCRC61056) and UWA provided a Scholarship for International Research Fees. Both organizations and the Commonwealth Scientific and Industrial Research Organisation provided operating funds. UWA and the Western Australian Department of Primary Industries and Regional Development both provided laboratory facilities for this research.

Ethics Statement: Approval for sampling in Papua New Guinea was obtained from the National Agriculture Quarantine and Inspection Authority, Port Moresby. Permission to import plant material blotted onto FTA cards was obtained from the Australian Federal Department of Agriculture, who granted permit number 0000450358 .

*The $\boldsymbol{e}$-Xtra logo stands for "electronic extra" and indicates that three supplementary tables are published online.

The author(s) declare no conflict of interest.

Accepted for publication 17 November 2018.

(C) 2019 The American Phytopathological Society
Worldwide, tropical and subtropical cucurbit crops suffer from a disease caused by Zucchini yellow mosaic virus (ZYMV; family Potyviridae; genus Potyvirus) (Coutts et al. 2011a; Desbiez and Lecoq 1997; Lecoq and Katis 2014; Zitter et al. 1996). ZYMV has flexuous filamentous particles 680 to $730 \mathrm{~nm}$ in length (Desbiez and Lecoq 1997; Lisa et al. 1981). More than 10 aphid species transmit it nonpersistently (Castle et al. 1992; Desbiez and Lecoq 1997; Katis et al. 2006; Yuan and Ullman 1996) and the virus is also contact transmitted (Coutts et al. 2013) and seedborne at low levels (Coutts et al. 2011b; Robinson et al. 1993; Schrijnwerkers et al. 1991). Volunteer cucurbitaceous crop and weed plants act as infection sources for ZYMV spread to cucurbit crops (Coutts and Jones 2005; Coutts et al. 2011b; Lecoq and Desbiez 2008). It can also move to new locations in ZYMV-infected fruit from which aphids can acquire and spread it (Lecoq et al. 2003). Foliage symptoms of mosaic, chlorosis, leaf deformation, and plant stunting develop in ZYMV-infected cucurbit crops. Infected fruit develop quality defects involving malformation and surface discoloration (Blua and Perring 1989; Coutts et al. 2011a; Desbiez and Lecoq 1997; Gal-On 2007). ZYMV infection causes major losses to cucurbit crops growing in Australia's subtropical west (Gascoyne region of Western Australia [WA]), tropical northwest (Kimberley region of WA), and topical north (Northern Territory [NT]) (Coutts and Jones 2005; Jones 1996). It also causes losses in cucurbit crops in its subtropical east (northern New South Wales [NSW]) and subtropical and tropical northeast (Queensland [QLD]) (Büchen-Osmond et al. 1988; Greber et al. 1987, 1988). In Australia's three northern neighbors, ZYMV infects cucurbit crops in Indonesia, East Timor, and Papua New Guinea (PNG) (CABI 
2016; Daryono and Natsuaki 2016; Davis et al. 2002; Maina et al. 2017a; Somowiyarjo 1993). In Southeast Asia, ZYMV also occurs in Malaysia, Singapore, and Vietnam (AVA 2001; CABI 2016; EPPO 2014; Fujisawa et al. 1986, 1990; Ha et al. 2008; Wong et al. 1992, 1994).

In Australia, agriculture only started in 1788 following European colonization, and in remote regions as recently as the 1960s. By contrast, in Southeast Asia, it has been practiced for more than 8,000 years (Hutterer 1983) and, in PNG in Oceania, for more than 6,000 years (Denham et al. 2003). For this reason, many viruses and virulent biological virus strains that cause damaging crop diseases elsewhere in the world only arrived recently or remain absent. Trade in plants and plant products involving unknowingly infected seed or vegetative propagules is responsible for most introductions (Gibbs et al. 2008; Jones 2009). Monsoonal winds blow from Australia's northern neighbor's across the sea toward northern Australia. These monsoonal winds could bring viruliferous insect vectors, thus introducing viruses (Boyle et al. 2014; Eagles et al. 2013, 2014; Firth et al. 2017; Johansen et al. 2001, 2003). Introductions could also occur from migrating birds carrying virus-infected seed in their intestines or discarded infected cucurbit fruit left behind by fishermen from neighboring countries camping on the shore (Gibbs et al. 2008). "Genetic connectivity" is a biosecurity term used when genetically similar nucleotide sequences are found among virus populations derived from different countries. Analysis of nucleotide sequences suggested that spread of ZYMV and two other nonpersistently aphid-borne potyviruses, Sweet potato feathery mottle virus (SPFMV) and $\mathrm{Pa}$ paya ringspot virus (PRSV), might have occurred in this way. ZYMV isolates from Kununurra in the East Kimberley region of WA demonstrated genetic connectivity with isolates from East Timor (Coutts et al. 2011b; Maina et al. 2017a), as did SPFMV isolates from Cairns in northeast QLD and Kununurra (Maina et al. 2018a,c). PRSV isolates from PNG demonstrated genetic connectivity with isolates from Ayr in northeast QLD, Darwin in the NT, and Broome in the West Kimberley region of WA (Maina et al. 2019). However, no genetic connectivity was found between genomic isolates from northern Australia or East Timor with a fourth potyvirus, Sweet potato virus $C$ (Maina et al. 2018a,c).

Coutts et al. (2011b) obtained 42 ZYMV coat protein (CP) sequences from cucurbit crops or cucurbitaceous weeds from five locations in mainland Australia, including four in the continents' north. Maina et al. (2017a) obtained 15 new ZYMV genomic sequences from cucurbit crops, 12 from two locations in northern Australia, and 3 from East Timor. They used these $\mathrm{CP}$ and genomic sequences to investigate (i) whether genetic connectivity occurs between these ZYMV populations or between them and ZYMV populations from other world regions and (ii) whether any of them were recombinants. As mentioned above, both studies found evidence of genetic connectivity between Southeast Asian ZYMV isolates and ZYMV isolates from Kununurra in Australia's West Kimberley region but genetic connectivity with ZYMV isolates from the other Australian regions was absent. To further test the hypothesis that plant viral pathogens of economically important crops are spreading into tropical northern Australia from its northern neighbors, we studied whether any genetic connectivity exists between ZYMV populations from PNG, northern Australia, and East Timor. For this, we compared the nucleotide sequences of the 9 new ZYMV sequences from PNG with those of the 12 Australian, 3 East Timorese, and 49 ZYMV genome sequences from elsewhere retrieved from GenBank. We also used the most up-to-date recombination analysis program to improve current understanding of its phylogenetics and provide new recombination information.

\section{Materials and Methods}

Isolate collection. In October 2016, cucumber or pumpkin plants with virus-like symptoms growing in multiple smallholder farms in the Bagl, Kongop, Lilinga, and Zage Villages in PNG's highlands were sampled; 23 leaf samples (1 leaf/plant) were collected (Fig. 1; Table 1). Each sample was blotted onto FTA Classic Cards (GE Healthcare) as described by Ndunguru et al. (2005) and sent to Australia after being air dried for $10 \mathrm{~min}$ at room temperature.

RNA extraction and reverse-transcription polymerase chain reaction. The 23 PNG samples blotted onto FTA cards were sampled by punching from each sample up to 20 discs, each approximately $2 \mathrm{~mm}$ in diameter. The 20 discs from each blotted sample were pooled and used to extract total RNA using a ZR Plant RNA MiniPrep kit (Zymo Research) following the manufacturer's instructions. Crude RNA was treated and quality control was undertaken as described previously (Guerret et al. 2017; Maina and Jones 2017; Maina et al. 2016a,b,c,d,e,f, 2017a,b,c,d,e,f, 2018a,b,c). Reversetranscription polymerase chain reaction (RT-PCR) was done using generic LegPotyF and LegPotyR primers (Webster 2008), and 13 of the samples were potyvirus positive when RT-PCR was done.

High-throughput sequencing. RNASeq libraries were prepared from the 13 potyvirus-positive sample extracts using $1 \mu \mathrm{g}$ of total RNA with a TruSeq Stranded Total RNA Sample Preparation kit incorporating Ribozero Plant (Illumina) as described previously (Guerret et al. 2017; Maina and Jones 2017; Maina et al. 2016a,b,c,d,e,f, 2017a,b,c,d,e,f, 2018a,b,c). The final size and concentration of each library was verified using Qubit and D1000 ScreenTape (TapeStation 2200; Agilent Technologies). The stranded libraries were sent to Macrogen Inc., where they were subjected to HiSeq 2500 using a TruSeq SBS KIT v4 (Illumina) with 151 cycles to generate paired-end reads in a multiplex of 24 samples in one lane.

Sequence analysis. After sequencing, RNA-Seq reads were subjected to analysis with CLC Genomics Workbench 6.5 (CLCGW) (CLC Bio, Qiagen) for quality control followed by subsequent de novo assemblies, as described previously (Kehoe et al. 2014a; Maina and Jones 2017; Maina et al. 2016a,b,c,d,e,f, 2017a,b,c,d,e,f, 2018a, $\mathrm{b}, \mathrm{c})$. In addition, reference mapping was used to verify de novo assembly contig quality. For this, the trimmed reads were imported into Geneious 8.1.7. (Biomaters Ltd.) (Kearse et al. 2012) before reference mapping to a sequence from GenBank, as described previously (Kehoe et al. 2014a). Then, both sequences were aligned to generate a consensus sequence which proved identical to the de novo sequence. All contigs were subjected to CLCGW BLASTn search tool and, subsequently, to PASC sequence comparisons (Altschul et al. 1990; Bao et al. 2014). Further analyses were done with all contigs with plant virus matches, consensus sequence integrity was investigated, and its full-length polyprotein was used with the contig of interest from CLCGW. Then, both were aligned in Geneious using MAFFT (Katoh et al. 2002) to create a final sequence. Open reading frames were predicted and annotations made using Geneious. Screening for vector contamination was undertaken using the National Center for Biotechnology Information vector screen tool (https://www.ncbi.nlm.nih.gov/tools/vecscreen). Finalized sequences were designated as full coding sequences based on comparison with the reference sequences used in the mapping process, or nearly full if some of the $5^{\prime}$ or $3^{\prime}$ untranslated region was missing but the polyprotein coding regions were intact. Percentage nucleotide identity scores between genomes were calculated using the pairwise function in Geneious with the number of differences model (Kearse et al. 2012), and a matrix of nucleotide identities was produced using Sequence Demarcation tool v1 (Muhire et al. 2014). Ten new ZYMV sequences from PNG were obtained, the sequences from samples $1 \mathrm{~A}$ and $12 \mathrm{~A}$ being identical and the sequence from sample 22A only being partial (Table 1). As reported previously by Maina et al. (2019), three samples with ZYMV (8A, 17B, and 22A) also contained PRSV. Nine genomic ZYMV sequences were deposited in GenBank under the accession numbers MH700743 to MH700751.

Recombination detection. Before recombination analysis was undertaken, to avoid upsetting the RDP analysis, 7 genomes with identical sequences from PNG and Australia were deleted from the alignments, leaving 66 of the original 73 sequences. Therefore, recombination analysis included the coding sequences of 7 ZYMV genomes from PNG, 7 from Australia, 3 from East Timor (Maina et al. 2017a), and 49 from elsewhere (Table 1; Supplementary Table S1). RDP version 5.2 (Martin et al. 2015) was used to detect putative recombination breakpoints between these 66 sequences. Any detected 
recombination signals flagged by RDP5.2 as potentially arising through evolutionary processes other than recombination were disregarded. Default parameters were used for the seven recombination detection methods implemented: RDP5.2 (Martin et al. 2005), GENECONV (Padidam et al. 1999), Bootscan (Martin et al. 2005), MaxChi (Smith 1992), Chimaera (Posada and Crandall 2001), SiScan (Gibbs et al. 2000), and Topal (McGuire and Wright 2000). Only potential recombination events with an associated Bonferroni-corrected $P$ value $<0.05$ for four or more recombination detection methods were considered credible evidence of recombination (Ohshima et al. 2002). The BURT method of Martin et al. (2015) was used to infer the locations and 95\% confidence intervals of breakpoint locations. Recombination breakpoint locations and origins of sequence regions potentially transferred during recombination were verified individually using the phylogenetic tools implemented in RDP5.2. A maximum-likelihood phylogenetic tree accounting for recombination was constructed using RAxML (Martin et al. 2015) with the GTR-CAT model and 100 bootstrap replicates.

Phylogenetics and nucleotide identities. Using ClustalW in MEGA 7.0.14 (Kumar et al. 2016; Larkin et al. 2007), the coding regions of the 9 new ZYMV sequences from PNG were aligned with those of 64 other nonredundant ZYMV genome sequences retrieved from GenBank. These 64 genomes included 49 from other parts of the world, plus 3 from East Timor and 12 from Australia (Table 1). An additional alignment included only the coding regions of the 24 entirely nonrecombinant and nonidentical genomic sequences. The entire alignment was subjected to Geneious to generate percentage nucleotide identities (Katoh et al. 2002). Phylogenetic analysis was used to compare the coding regions of (i) all 9 new ZYMV genomes from PNG, along with the 15 sequenced previously from Australia and East Timor, with 49 other ZYMV genomes from GenBank, and (ii) all nonrecombinant sequences, which consisted of 3 from Australia, 1 from East Timor, and 20 others from GenBank. Maximum-likelihood phylogenetic trees were constructed using the Tamura-Nei model, which was the best fitting of the eight models tested in MEGA 7.0.14 (Kumar et al. 2016), with bootstrap support values of 1,000. The codon positions included were first + second + third + noncoding. All ambiguous nucleotide positions were removed for each sequence pair. The trees were rooted with PRSV E2 (KC345609). The within-virus species phylogroup classification system adopted uses a neutral nomenclature system involving letters of the alphabet and Latinized numerals that avoid potentially misleading names based on biology or geography (Jones and Kehoe 2016; Maina et al. 2017b).

\section{Results}

Natural infection. The 10 ZYMV genomes obtained were from multiple smallholder farms in PNG's Highlands region (Fig. 1; Table 1). Nine came from cucurbit crop plants showing mosaic symptoms growing in Zage Village, Goroka District, Eastern Highlands Province. Two of these Zage samples were from pumpkin $(8 \mathrm{~A}$ and $22 \mathrm{~A})$ and seven from cucumber $(1 \mathrm{~A}, 9 \mathrm{~A}, 10 \mathrm{~A}, 14 \mathrm{~B}, 15 \mathrm{~B}$, $16 \mathrm{~B}$, and $17 \mathrm{~B})$. The remaining sample (12A) was from a cucumber plant with mosaic growing in Kongop Village, Mount Hagen District, Western Highlands Province. The numbers of samples with ZYMV from each location were 9 of 12 from Zage, 0 of 2 from Bagl, 1 of 7 from Kongop, and 0 of 2 from Lilinga (Bagl and Lilinga are in the Mount Hagen District).

High-throughput sequence data. RNA-Seq analysis of the 10 PNG sample extracts with ZYMV revealed $15,830,190$ to $21,979,924$ raw paired-end reads which reduced to $15,824,637$ to 20,810,866 after quality control (Supplementary Table S2). Using

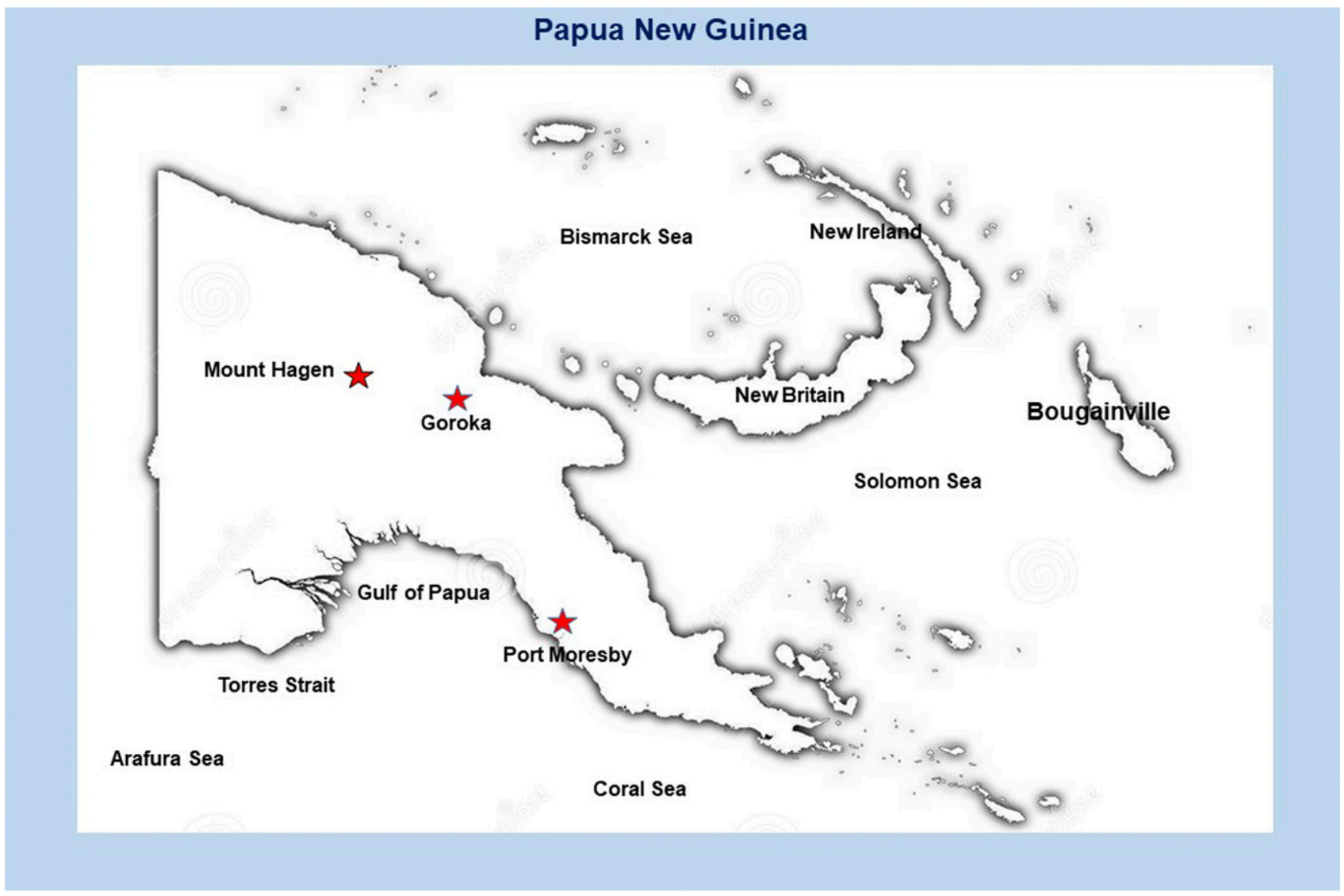

Fig. 1. Map of Papua New Guinea showing locations of Mount Hagen and Goroka, the capital cities of the Western and Eastern Highlands Provinces, respectively. Leaf samples were collected from cucurbit crops growing in multiple smallholder farms near Bagl, Kongop, and Lilinga Villages in the Mount Hagen District of the Western Highlands Province and Zage in the Goroka District of the Eastern Highland Province. Samples collected were blotted onto FTA cards, which were then sent to Australia for analysis. 
CLCGW de novo assembly, the numbers of contigs produced were 76 to 1,777 and the numbers of reads mapping to the contig of interest were 185,217 to $7,800,403$. The contigs of interest were more than 9,857 nucleotides (nt) in length, with average coverage of 3,322 to 79,269 . Final sequence lengths consisted of the consensus of the contig from CLCGW and the consensus from Geneious, and were deposited as GenBank accession numbers MH700743 to MH700751. Ten samples yielded ZYMV genomic sequences but $22 \mathrm{~A}$ provided only a partial ZYMV sequence. The PRSV sequences also present in samples $8 \mathrm{~A}, 17 \mathrm{~B}$, and 22A were reported previously (Maina et al. 2019).

Phylogenetic relationships. When the coding regions of all 9 new genomic sequences from PNG were compared with those of the 64 other genomes from GenBank, the analysis revealed the predicted clustering into major phylogroups A and B (Fig. 2A). Major phylogroup A contained minor phylogroups I to VI, as reported previously (Maina et al. 2017a), but three new ones were also present (VII to IX). Major phylogroup B included only the eight sequences analyzed previously (Maina et al. 2017a): three each from Kununurra and East Timor and one each from Singapore and Reunion Island. The nine new PNG sequences all clustered together, forming new minor phylogroup VII within major phylogroup A. Minor phylogroups I to $\mathrm{V}$ remained unaltered from those reported by Maina et al. (2017a); the seven sequences from Broome were in minor phylogroup I and the two from Darwin in minor phylogroup II. Minor phylogroup VI contained an additional sequence from Japan. New phylogroups VII and IX consisted of two or one new sequences, respectively, from China. New phylogroup VIII consisted of seven isolates from East Asia.

Recombination. When the coding regions of the 7 new ZYMV sequences from PNG were compared with the coding regions of the 59 sequences retrieved from GenBank, 25 sequences lacked any recombination while 30 firm recombination events were detected within the remaining 41 sequences, each event being supported by four or more programs implemented within RDP5.2. There were 21 sequences without recombination events in major phylogroup $\mathrm{A}$, whereas there were only 4 such sequences within major phylogroup B. The PNG sequences within new minor phylogroup VII were all recombinants, and, as reported previously using RDP4.72 (Maina et al. 2017a), so were all of the Australian sequences in minor phylogroup I, as was sequence TM16 from East Timor in major phylogroup B. Also, recombinants were present in all of the minor phylogroups, with the single exception of minor phylogroup II (Table 2). In phylogroup $\mathrm{B}$, in addition to Southeast Asian sequences SIN (AF024811) from Singapore and TM16 (KY225545) from East Timor, RDP 4.72 found Kununurra sequence 694K (KY225543) to be recombinant (Maina et al. (2017a). However, when analyzed by RDP5.2, although recombination was still indicated for $694 \mathrm{~K}$, it generated the RDP command "potentially arising through evolutionary processes other than recombination" and, thus, was disregarded.

Table 1. Details of the 10 Zucchini yellow mosaic virus isolates sequenced from Papua New Guinea (PNG) and those sequenced previously from Australia and East Timor

\begin{tabular}{|c|c|c|c|c|c|c|}
\hline Isolate $^{\mathbf{a}}$ & Host & $\begin{array}{l}\text { Symptoms in naturally infected } \\
\text { source plant }\end{array}$ & Geographical origin ${ }^{b}$ & $\begin{array}{l}\text { Year of } \\
\text { isolation }\end{array}$ & $\begin{array}{c}\text { Accession } \\
\text { numbers }\end{array}$ & Isolate origin \\
\hline$\overline{1 \mathrm{~A}}$ & Cucumber & Virus-like & Zage, Goroka, EHP, PNG & 2016 & MH700743 & This study \\
\hline $8 A^{*}$ & Pumpkin & Virus-like & Zage, Goroka, EHP, PNG & 2016 & MH700744 & This study \\
\hline $9 \mathrm{~A}$ & Cucumber & Virus-like & Zage, Goroka, EHP, PNG & 2016 & MH700745 & This study \\
\hline $10 \mathrm{~A}$ & Cucumber & Virus-like & Zage, Goroka, EHP, PNG & 2016 & MH700746 & This study \\
\hline $12 \mathrm{~A}$ & Cucumber & Virus-like & $\begin{array}{l}\text { Kongop, Mount Hagen, WHP, } \\
\text { PNG }\end{array}$ & 2016 & MH700749 & This study \\
\hline $14 \mathrm{~B}$ & Cucumber & Virus-like & Zage, Goroka, EHP, PNG & 2016 & MH700747 & This study \\
\hline $15 \mathrm{~B}$ & Cucumber & Virus-like & Zage, Goroka, EHP, PNG & 2016 & MH700748 & This study \\
\hline $16 \mathrm{~B}$ & Cucumber & Virus-like & Zage, Goroka, EHP, PNG & 2016 & MH700750 & This study \\
\hline $17 \mathrm{~B}^{*}$ & Cucumber & Virus-like & Zage, Goroka, EHP, PNG & 2016 & MH700751 & This study \\
\hline $22 \mathrm{~A}^{*}$ & Pumpkin & Virus-like & Zage, Goroka, EHP, PNG & 2016 & Incomplete & This study \\
\hline TM16 & Pumpkin & Virus-like & Loes, East Timor & 2015 & KY225545 & $\begin{array}{l}\text { Maina et al. } \\
\text { 2017a }\end{array}$ \\
\hline TM39 & Pumpkin & Virus-like & Aileu, East Timor & 2015 & KY225544 & $\begin{array}{l}\text { Maina et al. } \\
\text { 2017a }\end{array}$ \\
\hline TM40 & Cucumber & Virus-like & Aileu, East Timor & 2015 & KY225556 & $\begin{array}{l}\text { Maina et al. } \\
\text { 2017a }\end{array}$ \\
\hline $13 \mathrm{Br}$ & Zucchini & Mosaic, leaf deformation & Broome, WA, Australia & 2015 & KY225555 & $\begin{array}{l}\text { Maina et al. } \\
\text { 2017a }\end{array}$ \\
\hline $14 \mathrm{Br}$ & Zucchini & Mosaic, leaf deformation & Broome, WA, Australia & 2015 & KY225553 & $\begin{array}{l}\text { Maina et al. } \\
\text { 2017a }\end{array}$ \\
\hline $17 \mathrm{Br}$ & Zucchini & $\begin{array}{l}\text { Mosaic, chlorosis, reduction in } \\
\text { leaf size, plant stunting }\end{array}$ & Broome, WA, Australia & 2015 & KY225552 & $\begin{array}{l}\text { Maina et al. } \\
\text { 2017a }\end{array}$ \\
\hline $19 \mathrm{Br}$ & Zucchini & Mosaic, leaf deformation & Broome, WA, Australia & 2015 & KY225551 & $\begin{array}{l}\text { Maina et al. } \\
\text { 2017a }\end{array}$ \\
\hline $20 \mathrm{Br}$ & Zucchini & Mosaic, leaf deformation & Broome, WA, Australia & 2015 & KY225550 & $\begin{array}{l}\text { Maina et al. } \\
\text { 2017a }\end{array}$ \\
\hline $21 \mathrm{Br}$ & Zucchini & Mosaic, leaf deformation & Broome, WA, Australia & 2015 & KY225554 & $\begin{array}{l}\text { Maina et al. } \\
\text { 2017a }\end{array}$ \\
\hline $56 \mathrm{Br}$ & $\begin{array}{c}\text { Halloween } \\
\text { pumpkin }\end{array}$ & Mosaic & Broome, WA, Australia & 2015 & KY225549 & $\begin{array}{l}\text { Maina et al. } \\
\text { 2017a }\end{array}$ \\
\hline $694 \mathrm{~K}$ & $\begin{array}{l}\text { Jarrahdale } \\
\text { pumpkin }\end{array}$ & Yellow mosaic & Kununurra, WA, Australia & 1996 & KY225543 & Jones 1996 \\
\hline $695 \mathrm{~K}$ & $\begin{array}{l}\text { Jarrahdale } \\
\text { pumpkin }\end{array}$ & Mosaic & Kununurra, WA, Australia & 1996 & KY225542 & Jones 1996 \\
\hline $697 \mathrm{~K}$ & Honeydew melon & Mosaic & Kununurra, WA, Australia & 1996 & KY225546 & Jones 1996 \\
\hline $38 \mathrm{NT}$ & Honeydew melon & Mosaic, leaf deformation & Darwin, NT, Australia & 2011 & KY225548 & Barry Conde \\
\hline $75 \mathrm{NT}$ & Rockmelon & Mosaic, leaf deformation & Darwin, NT, Australia & 2011 & KY225547 & Barry Conde \\
\hline
\end{tabular}

${ }^{a}$ An asterisk (*) indicates samples which also contained PRSV (Maina et al. 2019).

${ }^{\mathrm{b}}$ EHP $=$ Eastern Highlands Province, WHP = Western Highlands Province, WA = Western Australia, and NT = Northern Territory. 
Most of the recombination breakpoints detected were in ZYMV's P1, CI, HC-Pro, P3, CP, and NIb regions, whereas its 6K2, NIa, and VPg regions contained fewer breakpoints $(<5)$ (Table 2). Isolate 17B from PNG had firm recombination breakpoints within its P1 and HC-
Pro regions. Although this shared event was present in the other six PNG sequences analyzed by RDP5.2, the beginnings and ends of their recombination breakpoints varied from positions 414 to 1,808 (Fig. 3A). The parental sequences for these PNG isolates were all

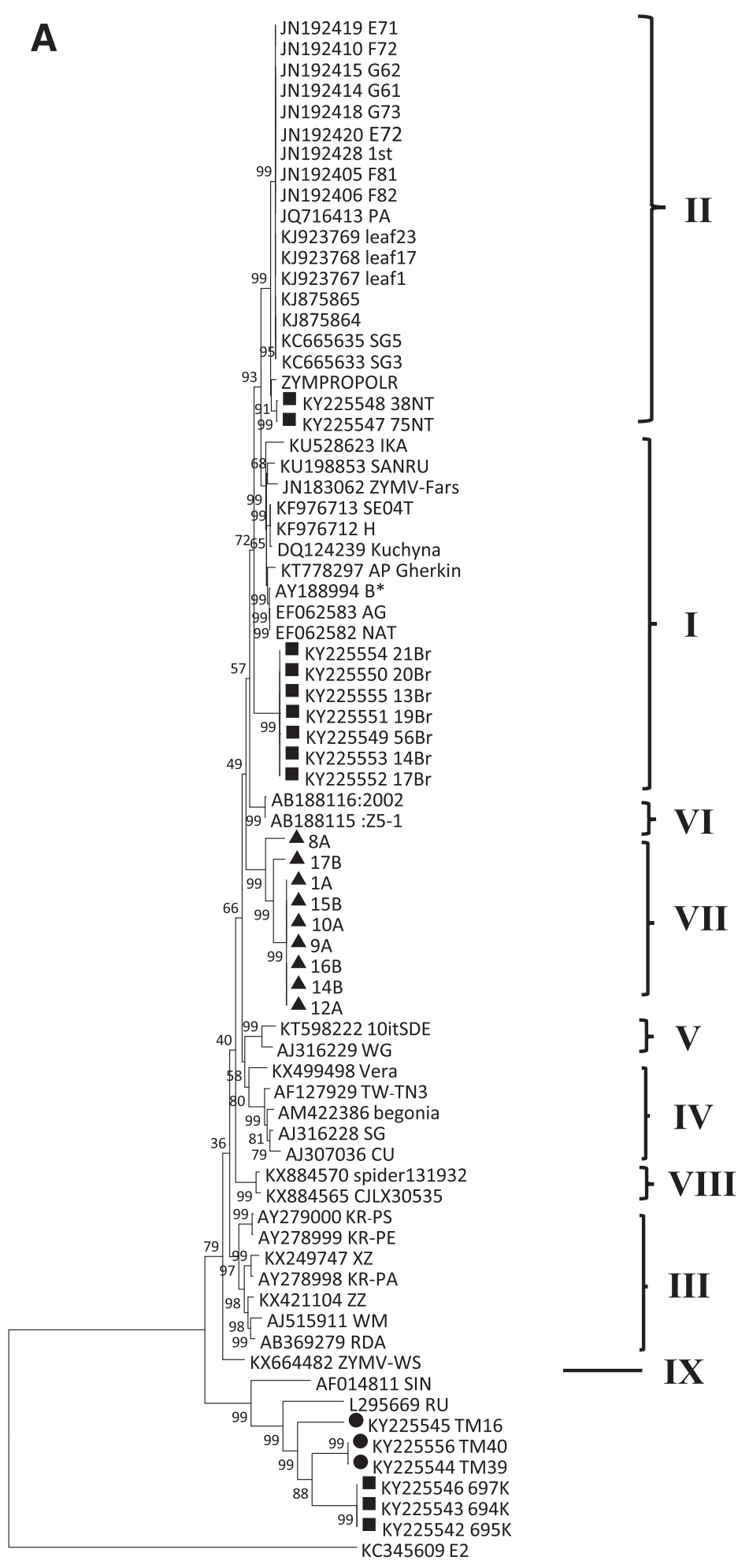

A

0.1 Substitutions per site

(Continued)

Fig. 2. Maximum-likelihood phylograms obtained from alignment of nucleotide sequences of Zucchini yellow mosaic virus (ZYMV). Comparisons were made between A, the following nonrecombinant and recombinant sequences: nine from Papua New Guinea (PNG) sequenced in this study, 15 from Australia and East Timor sequenced previously, and 49 other ZYMV genomes from elsewhere obtained from GenBank; and B, the following nonrecombinant sequences: 3 Australian and 1 East Timorese genome sequences published previously, and 20 other genome sequences from elsewhere obtained from GenBank. Trees were created in MEGA 7.0.14 using ClustalW with 1,000 replicates. Bootstrap values are percentages, with only values over 50\% shown at the nodes. Trees were rooted with Papaya ringspot virus (PRSV) E2 (KC345609). Symbols show the newly sequenced isolates from PNG $(\mathbf{\Delta})$, and the previously sequenced isolates from Australia ( $\mathbf{\square})$ and East Timor $(\mathbf{\bullet})$. 
KT778297 (major) and KY225549 (minor), $P$ value $8.604 \times 10^{-05}$. As reported by Maina et al. (2017a), all Broome sequences had three events involving their P1, HC-Pro, and P3 regions but, using RDP5.2 with all three events, both the major and minor parents changed. Sequence TM16 from East Timor again had firm recombination breakpoints within its P1 and HC-Pro regions, as reported previously (Maina et al. 2017a). However, with RDP5.2, its breakpoints shifted slightly and its major parent changed to RU (L295669) from Reunion Island.

When a recombinant-free phylogenetic tree was constructed from nonrecombinant genomes, major phylogroups A and B remained but minor phylogroups I, III, IV, V, VI, VII, and VIII were all absent, leaving only II and IX (Fig. 2B). However, when genomic sequences that included both nonrecombinants and recombinants were aligned and employed to construct a maximum-likelihood phylogenetic ZYMV tree from which regions with recombinationally derived sequence tracts were removed before analysis, the resulting tree provided evidence of five distinct minor phylogroups in addition to major phylogroups A and B (Fig. 3B). Within major phylogroup A, five former minor phylogroups remained unchanged (II, III, IV, V, and VII) (Fig. 2A) but there were mergers involving the other four minor phylogroups, with two merged minor phylogroups forming (I/VI and VIII/IX). These mergers were associated with complete disappearance of four former minor phylogroups (I, VI, VIII, and IX). Within merged minor phylogroup I/VI, there were four types of sequences, one type with two events involving one sequence only and three types with similar recombination patterns involving one event (nine sequences), three events (two sequences), and three events (four sequences). Within merged minor phylogroup VIII/ IX, there were two sequences each with the same three events, and one nonrecombinant sequence. In minor phylogroup VII (which contained all the PNG sequences), all seven sequences contained the same single event. In minor phylogroup III, there were five types of sequences: four sequences had two event patterns, and the other two sequences each had three unique event patterns. Minor phylogroup V had four events in two sequences, two of these events only occurring in single sequences, and minor phylogroup IV had four events among five sequences, two sequences having the same two events, and the other three having single unique (two sequences) or double (one sequence) events. In major phylogroup $\mathrm{B}$, there were two recombinant sequences, each with unique events.

Among nonrecombinant sequences alone, there was a bootstrap support value of $100 \%$ separating monophyletic minor phylogroup IX from the rest of major phylogroup A, fully supporting its separation from all other sequences (Fig. 2B). Therefore, this minor phylogroup containing only nonrecombinant sequence WS (KX664482) was retained to distinguish it from other minor phylogroups containing recombinants or nonrecombinants, despite the bootstrap support value being as low as $36 \%$ (Fig. 2A). When recombinationally derived portions of sequences were excluded, this nonrecombinant sequence fitted with two recombinant sequences within combined minor phylogroup VIII/IX (Fig. 3B).

Only 8A (MH700744) and 17B (MH700751) of our nine ZYMV genomic sequences from PNG came from samples with mixed infection with PRSV; therefore, artificial recombination, if it had taken place, could only have occurred with these two. However, there

Fig. 2. (Continued)

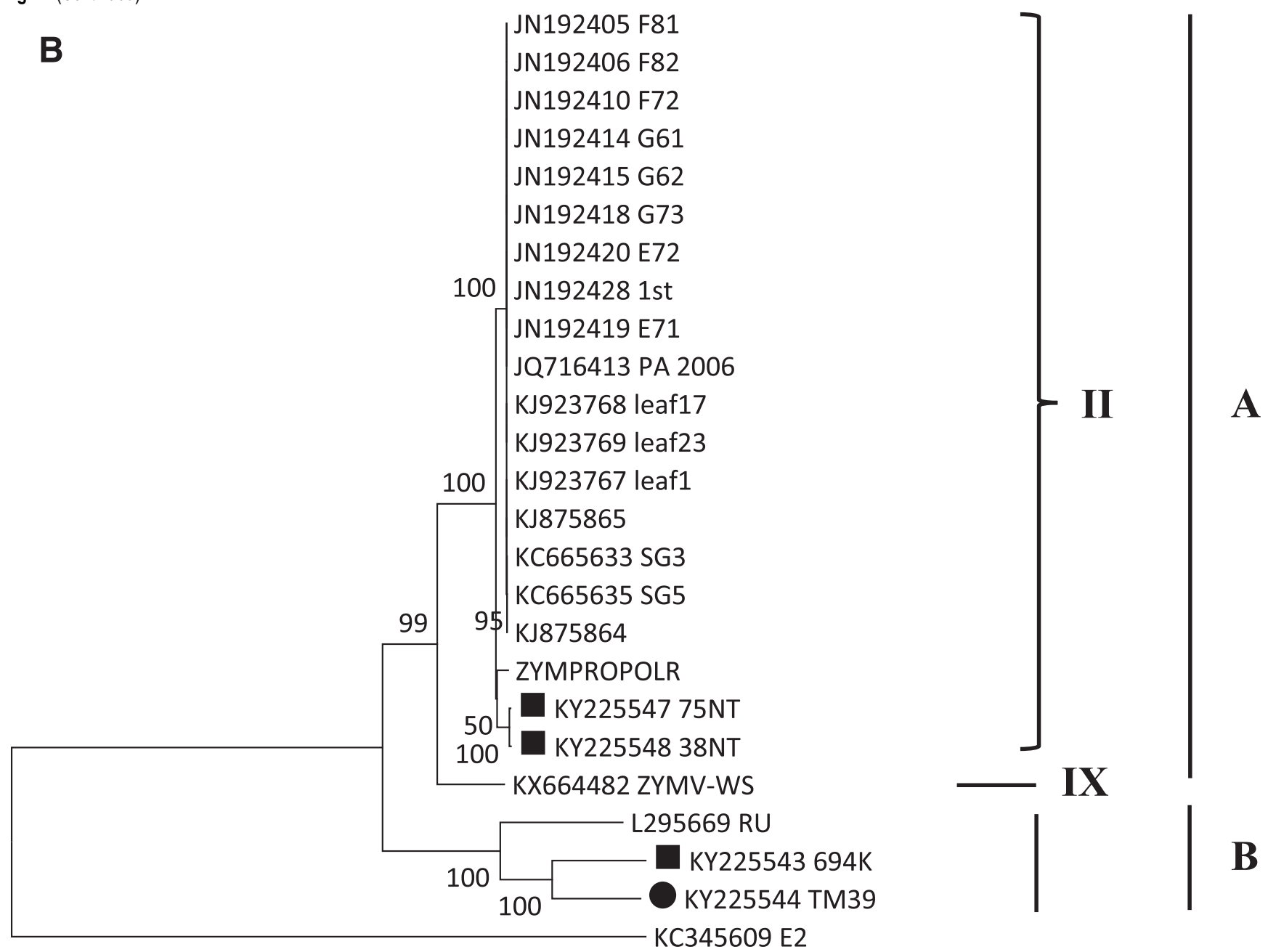

0.1 Substitutions per site 
was no evidence of this being so because (i) there were only 1 to 2 bootstrap value differences separating $8 \mathrm{~A}$ and $17 \mathrm{~B}$ from the other seven PNG sequences (Fig. 2A) and (ii) they both had exactly the same recombination events as those in the other seven PNG sequences (Table 2; Fig. 3B).

Sequence identities. When the coding regions of all the $73 \mathrm{ZYMV}$ genomes were analyzed, the greatest divergence between the different PNG sequences within major phylogroup A's minor phylogroup VII was the $94.5 \%$ nucleotide identity between sequences $8 \mathrm{~A}$ and 15B (Supplementary Table S3). The closest genetic matches between any PNG sequence within major phylogroup A's minor phylogroup VII and the Australian sequences within major phylogroup A's minor phylogroup's I and II involved $17 \mathrm{~B}$ from PNG and $56 \mathrm{Br}$ (KY225549) from Broome (phylogroup I) and 17B and 75NT (KY225547) from Darwin (phylogroup II), with 91.7 and 92.4\% nucleotide identities, respectively. The closest genetic match between a PNG sequence and any sequence from elsewhere was the $92.8 \%$ nucleotide identity between sequence $17 \mathrm{~B}$ from PNG and sequence Z51 (ABI88115) from Japan in phylogroup VI.

\section{Discussion}

This article describes the first ZYMV genomic sequences from cucurbit crops growing in PNG or elsewhere in Oceania apart from Australia, and the absence of genetic matches between PNG and northern Australian or East Timorese ZYMV populations demonstrates the lack of genetic connectivity between them. The PNG sequences came from the country's Eastern and Western Highlands, the Australian sequences were from widely dispersed locations spanning the north of the Australian continent, and the $92.8 \%$ nucleotide identity between a PNG sequence and the closest sequence from elsewhere suggests a single introduction. Such absence of genomic connectivity between PNG and Australian ZYMV sequences is inconsistent with the hypothesis that viral pathogens of important crops are arriving in tropical Australia by crossing the sea separating it from its northern neighbors. This contrasts with the genetic connectivity found previously between ZYMV sequences from Kununurra in northwest Australia and East Timorese sequences (Maina et al. 2017a). Absence of genetic connectivity between PNG and northern Australian ZYMV isolates indicates that, should isolates from PNG prove more virulent than those already present, they might pose a biosecurity threat to northern Australian agriculture. Recombination analysis undertaken with the latest RDP program (RDP5.2) predicted 30 recombination events involving 41 of 66 sequences, which is far more than in previous recombination analyses, and found that all PNG sequences analyzed showed evidence of recombination. This exceptionally high incidence of recombinants reflects rapid evolution of the virus to adapt to new circumstances (e.g., in PNG). Six regions of the ZYMV genome showed evidence of a high frequency of recombination breakpoints whereas, previously, only two regions had shown this. Removing recombinationally derived tracts from recombinant sequences beforehand, followed by recombination analysis of all combined recombinant and nonrecombinant nonredundant ZYMV genomes available on the database, allowed a comprehensive investigation of the relationships between ZYMV sequences from PNG and others from the rest of the world. Such an analysis has never been done before. A phylogenetic tree that included all genomic sequences contained two major and nine minor phylogroups, three of which were new; however, in a recombinant-free phylogenetic tree, although both major phylogroups were still present, only two minor phylogroups remained. By contrast, when the nonrecombinant data within recombinant sequences were aligned with the nonrecombinant sequences, although five of the previous minor phylogroups within major phylogroup A remained unaltered, four others combined, forming two merged minor phylogroups.

Table 2. Recombination events identified by the RDP5.2 package within Zucchini yellow mosaic virus genomes

\begin{tabular}{|c|c|c|c|c|c|c|c|c|c|}
\hline Events & Isolate $^{\mathbf{a}}$ & Group $^{b}$ & $\begin{array}{c}\text { Detected } \\
\text { recombinant }\end{array}$ & $\begin{array}{c}\text { Detected } \\
\text { breakpoint } \\
\text { position }\end{array}$ & Genes affected & $\begin{array}{c}\text { Major } \\
\text { parental } \\
\text { sequence }\end{array}$ & $\begin{array}{c}\text { Minor } \\
\text { parental } \\
\text { sequence }\end{array}$ & $\begin{array}{l}\text { Detected } \\
\text { methods in } \\
\text { RDP5.2 }\end{array}$ & Highest $P$ value \\
\hline 1 & $\mathrm{SG}^{(2)}$ & IV & AJ316228 & $8,636-8,666$ & $\mathrm{CP}$ & KF791028 & KY9333061 & R,G,B,M,C,S,T & $7.525 \times 10^{-32}$ \\
\hline 2 & IKA & I & KU528623 & $5,353-6,078$ & $6 \mathrm{~K} 2, \mathrm{VPg}$ & DQ124239 & AF127929 & $\mathrm{R}, \mathrm{G}, \mathrm{B}, \mathrm{M}, \mathrm{C}, \mathrm{S}, \mathrm{T}$ & $9.080 \times 10^{-29}$ \\
\hline 3 & KR-PS(2) & III & AY279000 & $3,677-6,676$ & $\mathrm{CI}, 6 \mathrm{~K} 2, \mathrm{VPg}, \mathrm{NIa}$ & AY278998 & KX884570 & $\mathrm{R}, \mathrm{G}, \mathrm{B}, \mathrm{M}, \mathrm{C}, \mathrm{S}, \mathrm{T}$ & $6.699 \times 10^{-26}$ \\
\hline 4 & SE04T ${ }^{(10)}$ & I & KF976713 & $6,424-10,108$ & $\mathrm{NIa}, \mathrm{NIb}, \mathrm{CP}$ & KY225548 & KY225549 & $\mathrm{R}, \mathrm{G}, \mathrm{B}, \mathrm{M}, \mathrm{C}, \mathrm{S}, \mathrm{T}$ & $8.123 \times 10^{-17}$ \\
\hline 5 & $\mathrm{XZ}$ & III & KX249747 & $6,526-7,752$ & $\mathrm{NIa}, \mathrm{NIb}$ & AY278998 & KX664482 & $\mathrm{R}, \mathrm{G}, \mathrm{M}, \mathrm{C}, \mathrm{S}, \mathrm{T}$ & $9.313 \times 10^{-12}$ \\
\hline 6 & $\mathrm{CU}$ & IV & AJ307036 & $9,617-10,212$ & $\mathrm{CP}$ & AJ316228 & KX664482 & $\mathrm{R}, \mathrm{G}, \mathrm{B}, \mathrm{M}, \mathrm{C}, \mathrm{S}, \mathrm{T}$ & $5.451 \times 10^{-05}$ \\
\hline 7 & $\mathrm{Z} 5-1^{(2)}$ & VI & $\mathrm{AB} 188115$ & $1-2,654$ & P1, HC-Pro & KY226647 & AJ316229 & $\mathrm{R}, \mathrm{G}, \mathrm{B}, \mathrm{M}, \mathrm{C}, \mathrm{S}, \mathrm{T}$ & $3.231 \times 10^{-11}$ \\
\hline 8 & $\mathrm{XZ}^{(7)}$ & III & KX249747 & $3,254-6,069$ & $\mathrm{CI}, 6 \mathrm{~K} 2, \mathrm{VPg}$ & KU198853 & KX664482 & $\mathrm{R}, \mathrm{G}, \mathrm{B}, \mathrm{M}, \mathrm{C}, \mathrm{S}, \mathrm{T}$ & $5.690 \times 10^{-08}$ \\
\hline 9 & SIN & B & AF014811 & $2,481-5,755$ & $\mathrm{P} 3, \mathrm{CI}, 6 \mathrm{~K} 2, \mathrm{VPg}$ & KY225544 & KY225547 & $\mathrm{R}, \mathrm{B}, \mathrm{M}, \mathrm{C}, \mathrm{S}, \mathrm{T}$ & $3.888 \times 10^{-06}$ \\
\hline 10 & CJLX30535(2) & VIII & KX884565 & $8,636-10,216$ & $\mathrm{CP}$ & AB369279 & L295669 & $\mathrm{G}, \mathrm{B}, \mathrm{M}, \mathrm{C}, \mathrm{S}, \mathrm{T}$ & $9.447 \times 10^{-06}$ \\
\hline 11 & $10 \mathrm{itSDE}^{(2)}$ & $\mathrm{V}$ & KT598222 & $2,472-4,758$ & $\mathrm{P} 3, \mathrm{CI}$ & L295669 & AF127929 & $\mathrm{R}, \mathrm{B}, \mathrm{M}, \mathrm{C}, \mathrm{S}, \mathrm{T}$ & $5.315 \times 10^{-09}$ \\
\hline 12 & $19 \mathrm{Br}^{(4)}$ & I & KY225551 & $3,107-4,140$ & P1, HC-Pro, P3 & AB 188116 & KY225547 & $\mathrm{R}, \mathrm{B}, \mathrm{M}, \mathrm{C}, \mathrm{S}, \mathrm{T}$ & $5.091 \times 10^{-04}$ \\
\hline 13 & $\mathrm{CU}^{(4)}$ & IV & AJ307036 & $374-1,648$ & P1, HC-Pro & KX499498 & KJ875864 & $\mathrm{R}, \mathrm{G}, \mathrm{B}, \mathrm{M}, \mathrm{C}, \mathrm{S}, \mathrm{T}$ & $7.427 \times 10^{-17}$ \\
\hline 14 & $2002^{(2)}$ & VI & AB188116 & $3,092-4,144$ & $\mathrm{P} 3, \mathrm{CI}$ & KJ875864 & KX499498 & $\mathrm{G}, \mathrm{M}, \mathrm{C}, \mathrm{S}, \mathrm{T}$ & $4.574 \times 10^{-08}$ \\
\hline 15 & CJLX30535(2) & VIII & KX884565 & $859-3,676$ & P1, HC-Pro, P3, CI & KY225548 & AY279000 & $\mathrm{G}, \mathrm{B}, \mathrm{M}, \mathrm{S}$ & $8.625 \times 10^{-08}$ \\
\hline 16 & $10 \mathrm{itSDE}^{(2)}$ & $\mathrm{V}$ & KT598222 & $6,445-7,239$ & $\mathrm{NIa}, \mathrm{NIb}$ & AJ515911 & L295669 & $\mathrm{R}, \mathrm{M}, \mathrm{C}, \mathrm{S}$ & $7.095 \times 10^{-03}$ \\
\hline 17 & WM & III & AJ515911 & $9,472-10,227$ & $\mathrm{CP}$ & KX421104 & KX664482 & $\mathrm{G}, \mathrm{M}, \mathrm{C}, \mathrm{S}$ & $4.807 \times 10^{-32}$ \\
\hline 18 & TM16 & B & KY225545 & $364-2,858$ & P1, HC-Pro & L295669 & KY225544 & $\mathrm{R}, \mathrm{G}, \mathrm{B}, \mathrm{M}, \mathrm{C}, \mathrm{S}$ & $8.140 \times 10^{-23}$ \\
\hline 19 & $\mathrm{CU}$ & IV & AJ307036 & $8,646-9,604$ & $\mathrm{CP}$ & AF127929 & $8 \mathrm{~A}$ & $\mathrm{R}, \mathrm{B}, \mathrm{M}, \mathrm{C}, \mathrm{S}$ & $7.416 \times 10^{-10}$ \\
\hline 20 & $\mathrm{XZ}$ & III & KX249747 & $7,772-9,902$ & $\mathrm{NIb}, \mathrm{CP}$ & AB369279 & AY278998 & $\mathrm{R}, \mathrm{G}, \mathrm{B}, \mathrm{M}, \mathrm{C}, \mathrm{S}, \mathrm{T}$ & $9.388 \times 10^{-06}$ \\
\hline 21 & $56 \mathrm{Br}^{(4)}$ & I & KY225549 & $472-3,060$ & P1, HC-Pro, P3 & KX884570 & KY225548 & $\mathrm{R}, \mathrm{B}, \mathrm{M}, \mathrm{C}, \mathrm{S}, \mathrm{T}$ & $4.478 \times 10^{-01}$ \\
\hline 22 & WG & $\mathrm{V}$ & AJ316229 & $7,230-7,555$ & $\mathrm{Nib}$ & KT598222 & KY225549 & $\mathrm{R}, \mathrm{G}, \mathrm{B}, \mathrm{M}, \mathrm{C}, \mathrm{S}, \mathrm{T}$ & $6.441 \times 10^{-07}$ \\
\hline 23 & $17 \mathrm{~B}^{(7)}$ & VII & $17 \mathrm{~B}$ & $414-1,808$ & P1, HC-Pro & KT778297 & KY225549 & $\mathrm{M}, \mathrm{C}, \mathrm{S}, \mathrm{T}$ & $8.604 \times 10^{-05}$ \\
\hline 24 & $10 \mathrm{itSDE}^{(2)}$ & $\mathrm{V}$ & KT598222 & $9-1,002$ & P1, HC-Pro & KX664482 & AY278999 & $\mathrm{B}, \mathrm{M}, \mathrm{C}, \mathrm{S}, \mathrm{T}$ & $2.313 \times 10^{-04}$ \\
\hline 25 & KR-PA & III & AY278998 & $142-1,471$ & P1, HC-Pro & AJ515911 & KX249747 & $\mathrm{R}, \mathrm{G}, \mathrm{B}, \mathrm{M}, \mathrm{C}, \mathrm{S}, \mathrm{T}$ & $8.846 \times 10^{-09}$ \\
\hline 26 & $X^{(6)}$ & III & KX249747 & $1,011-1,986$ & P1, HC-Pro & AB188116 & KT778297 & $\mathrm{R}, \mathrm{B}, \mathrm{M}, \mathrm{C}, \mathrm{S}, \mathrm{T}$ & $4.723 \times 10^{-08}$ \\
\hline 27 & $14 \mathrm{Br}^{(4)}$ & I & KY225553 & $9-352$ & P1, HC-Pro, P3 & KY225547 & AJ307036 & $\mathrm{R}, \mathrm{G}, \mathrm{B}, \mathrm{S}, \mathrm{T}$ & $9.932 \times 10^{-05}$ \\
\hline 28 & Spider131(2) & VIII & KX884570 & $7,519-8,449$ & $\mathrm{NIb}, \mathrm{CP}$ & AJ307036 & KU198853 & $\mathrm{M}, \mathrm{C}, \mathrm{S}, \mathrm{T}$ & $6.579 \times 10^{-03}$ \\
\hline 29 & $\mathrm{Z} 5-1^{(2)}$ & VI & AB188115 & $8,629-9,649$ & $\mathrm{NIb}, \mathrm{CP}$ & AY188994 & L295669 & $\mathrm{R}, \mathrm{M}, \mathrm{C}, \mathrm{T}$ & $3.393 \times 10^{-03}$ \\
\hline 30 & Vera & IV & KX499498 & $196-862$ & $\mathrm{P} 1$ & KU528623 & KX249747 & $\mathrm{R}, \mathrm{M}, \mathrm{C}, \mathrm{T}$ & $9.489 \times 10^{-04}$ \\
\hline
\end{tabular}

${ }^{\text {a }}$ Superscript numbers in parentheses represent numbers of sequences with shared events.

${ }^{\mathrm{b}}$ Phylogroup.

${ }^{\mathrm{c}}$ RDP 5.2 methods: $\mathrm{B}=$ Bootscsan, $\mathrm{C}=$ Chimera, $\mathrm{G}=$ Gencov, $\mathrm{M}=$ Maxchi, $\mathrm{R}=\mathrm{RDP}, \mathrm{S}=$ SiScan, and $\mathrm{T}=$ Topal. 
Previous studies suggested that three separate ZYMV introductions to Australia, one of which came from Southeast Asia, have taken place since agriculture started after European colonists first arrived 230 years ago (Coutts et al. 2011b; Maina et al. 2017a). Moreover, although previous genetic connectivity studies with PRSV found no evidence of its introduction to Australia from Southeast Asia (Maina et al. 2017b), they found evidence of genetic connectivity between PRSV sequences from northern Australia and PNG, suggesting a single introduction (Maina et al. 2019). In contrast, in the current study, no genetic connectivity was found between ZYMV sequences from Australia and PNG, the closest sequence to one from PNG being one from Japan (ABI88115) which was in a different minor phylogroup (within VI instead of VII, which contained the PNG sequences) and had only a $92.8 \%$ nucleotide identity with the closest PNG sequence (MH700751). Other evidence of windborne insect vectors blown from PNG bringing viruses into northeast Australia is available, such as Japanese encephalitis virus carried by viruliferous mosquitos or biting midges from PNG (Johansen et al. 2001, 2003), and Bluetongue virus carried by virus-infected biting midges from Indonesia, East Timor, and PNG (Boyle et al. 2014; Eagles et al. 2013, 2014; Firth et al. 2017; Onyango et al. 2015). However, we found no evidence of this occurring with ZYMV aphid vectors blown from PNG.

Viruses develop greater pathogenicity or virulence and invade new hosts through recombination (Chare and Holmes 2006; Desbiez et al. 2002; Gibbs and Ohshima 2010; Gibbs et al. 2008; James et al. 2016; Jones 2009; Kehoe et al. 2014b; Lai 1992; Maina et al. 2018c; Revers et al. 1996; Valli et al. 2007). Among the genomic sequences then available, Maina et al. (2017a) found six recombination events in 14 ZYMV sequences using the RDP4.7 recombination analysis package. All 10 sequences from northwest Australia, 1 each from East Timor and Singapore, and 2 from elsewhere were recombinants. Most recombination events occurred in ZYMV's P1 or CP regions. In our study, we used the most recent recombination package (RDP5.2) to search for recombinants among the increased number of genomic sequences of ZYMV now available. Our analysis found many more recombinant ZYMV sequences and 16 more firm recombination events, and all PNG sequences were recombinants. Moreover, there were differences in what was detected by the two packages; for example, RDP5.2 failed to detect firm recombination in sequence 694K (KY225543) from Kununurra although, previously, RDP4.7 had reported its presence. Also, when the same genomes were analyzed by both packages, RDP5.2 found two rather than one firm recombination events in ZYMV isolate Z5-1 (AB188115), and commonly detected recombination breakpoints not only within ZYMV's P1 and CP regions, as reported previously by Maina et al. (2017a) using RDP4.7, but also in ZYMV's Cl, NIaPro, P3, and NIb regions. Similarly, using RDP5.2 with SPFMV and Sweet potato virus $C$, Maina et al. (2018c) found a high frequency of recombination breakpoints not only within their $\mathrm{P} 1$ and $\mathrm{CP}$ regions but also in their NIa-Pro and NIb regions. Conversely, using older version recombination packages, studies with other potyviruses found recombination breakpoints most frequently in their P1, CI, and VPg regions (Desbiez and Lecoq 2008; Ohshima et al. 2007; Tan et al. 2004).

Exclusion of recombinant genomes and removal of recombinationally derived tracts of sequence from recombinant genomes before analysis are methods used to account for recombination during phylogenetic or evolutionary studies (Gibbs et al. 2017; Karasev et al. 2011; Maina et al. 2018b; Moury 2010; Ogawa et al. 2012; Santillan et al. 2018; Visser et al. 2012). Furthermore, when recombinationfree datasets are required but few genomic sequences are available, inclusion of recombinant genomes with recombinationally derived tracts of sequence removed prior to analysis is preferable to complete exclusion of all recombinants. Here, we followed the methodology employed by Maina et al. (2018c, 2019) to produce phylogenetic trees from all ZYMV genomic sequences, including recombinants without their recombinationally derived tracts. This approach retained five former minor phylogroups unaltered (II, III, IV, V, and VII) but resulted in the formation of two minor phylogroups (I/VI, VIII/IX) through mergers between the other four minor phylogroups, which disappeared as a consequence (Fig. 3B). These

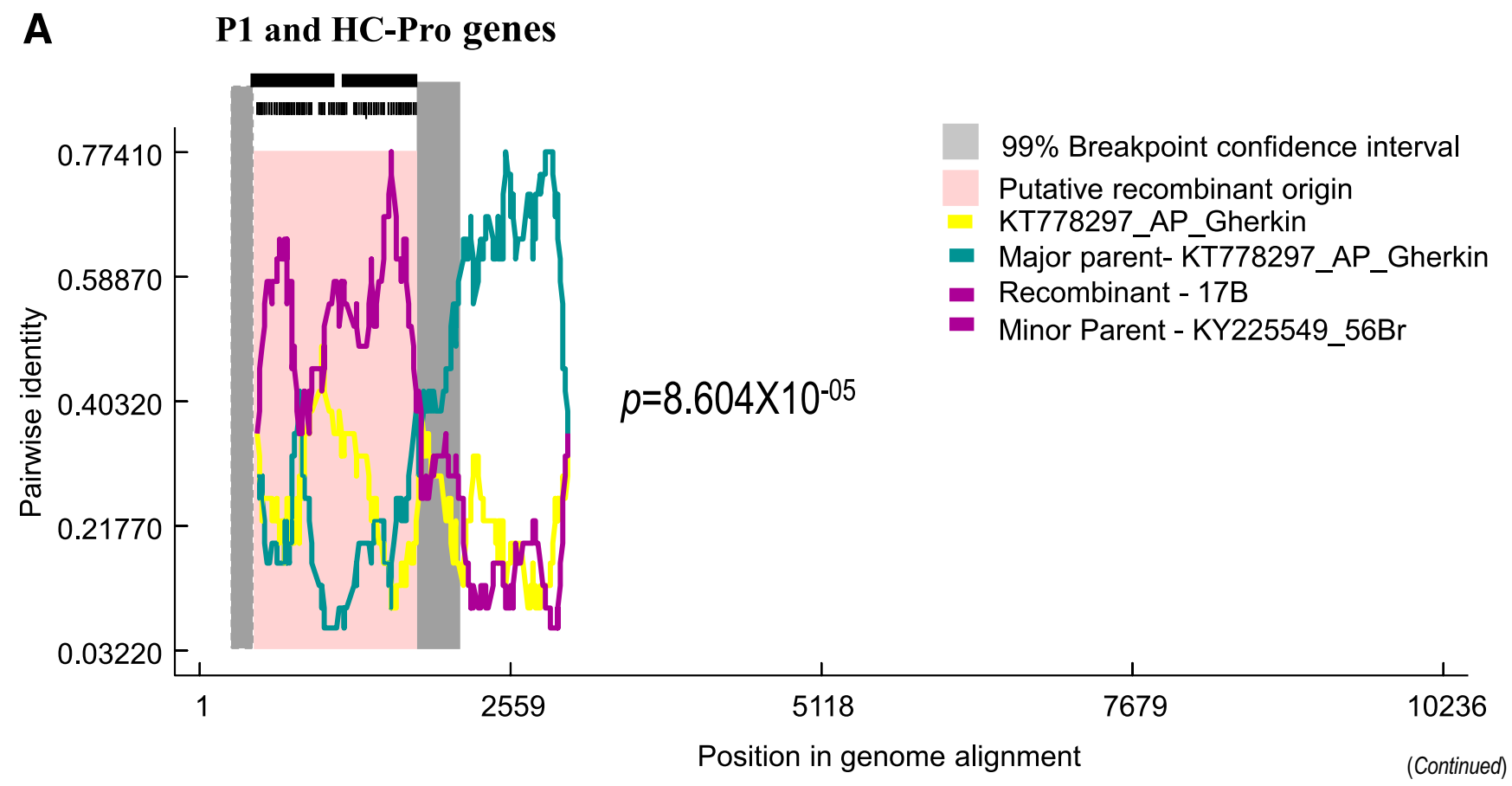

Fig. 3. A, Schematic representation of RDP pairwise plot and putative recombination breakpoints within the $P$ and HC-Pro genes among the seven Zucchini yellow mosaic virus (ZYMV) sequences (two identical sequences excluded) from Papua New Guinea (PNG). The left and right margins of the light-gray (pink in the online color version) region indicate breakpoints suggested by the RDP5.2 method. B, Maximum-likelihood phylogenetic tree obtained from nucleotide alignment of 66 ZYMV sequences from which any recombinant regions had been removed. The tree was inferred using PHYML/RAxML/FastTREE with 1,000 bootstrap test support, model GTR-CAT, and Faster RAxML tree search strategy in the RDP5.2 program. Black bars indicate entirely nonrecombinant sequences, dark gray (colored in the online version) denotes recombinant segments in sequences showing recombination, and light gray shows their nonrecombinant segments. In the online version, red denotes recombinant segments with the same events and green denotes recombinant segments showing unique events. Asterisks $\left(^{*}\right)$ indicate sequence groups with the same or similar recombination patterns. 
findings with ZYMV resemble those reported previously with PRSV (Maina et al. 2019) by providing insights that can only be obtained by removing recombinationally derived tracts of sequence before phylogenetic analyses. All nine ZYMV isolates from PNG in major phylogroup A minor phylogroup VII were recombinants and their percentage nucleotide identities diverged by up to $5.5 \%$. Similarly, all seven genomic sequences from Broome (which is in tropical northwest Australia) in major phylogroup A minor phylogroup I were recombinants by both the RDP4.7 (Maina et al. 2017a) and RDP5.2 packages. Such findings led Maina et al. (2017a) to suggest that the high recombination frequency found might reflect an evolutionary pathway enabling ZYMV to adapt rapidly to tropical conditions. Our findings with the new ZYMV sequences from PNG are consistent with this suggestion.

Due to the recent arrival of agriculture, many damaging viral pathogens or their virulent strains are absent from Australia. However, as

Fig. 3. (Continued)

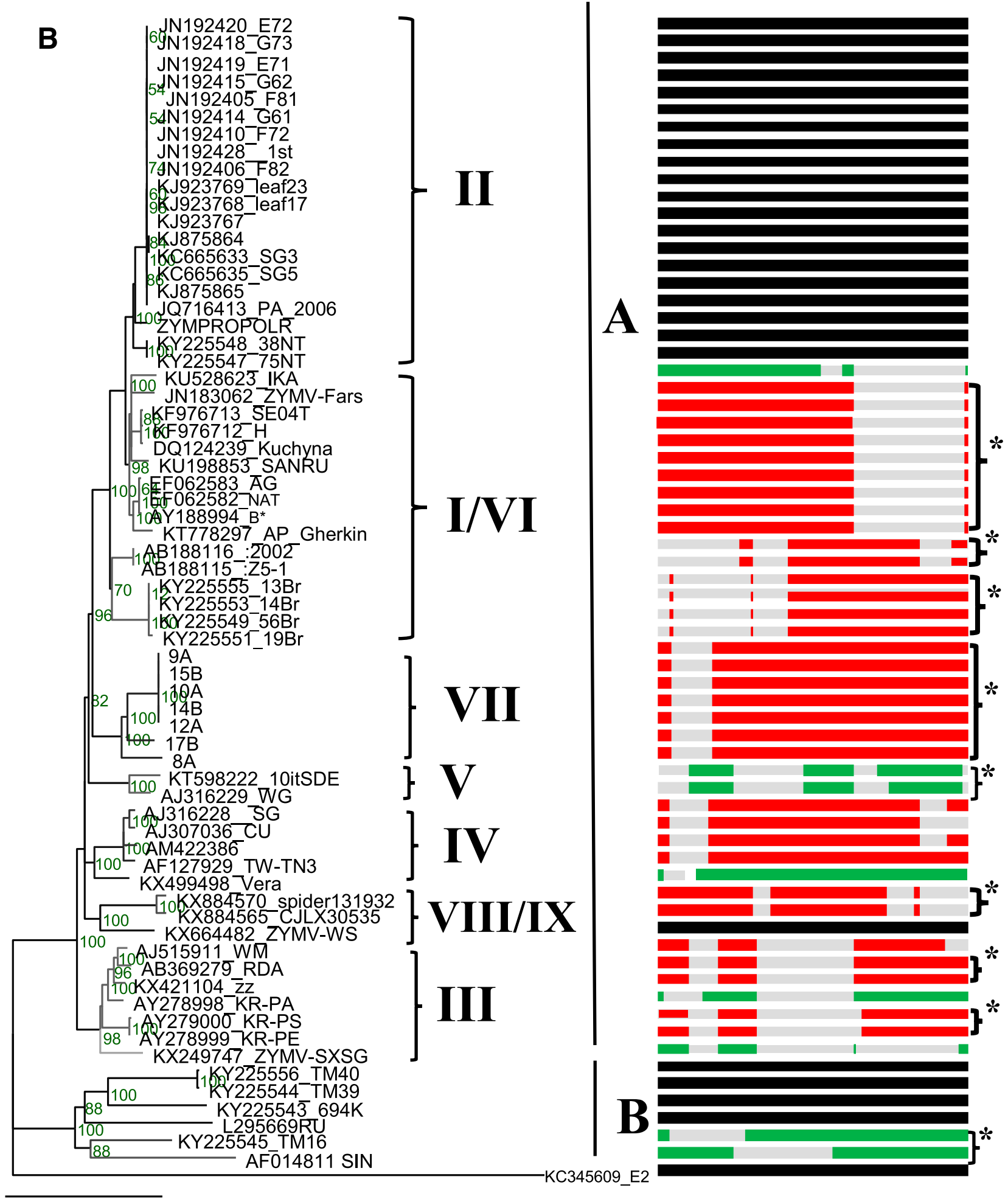

\subsection{Substitutions per site}


climate change causes the intensity of monsoonal winds to increase (Jones 2009, 2016; Jones and Barbetti 2012), virus introductions into Australia seem likely to expand in the future due to increased numbers of virus-carrying insect virus vectors arriving in the north of the continent. The lack of genetic connectivity between northern Australian and PNG ZYMV isolates indicates that isolates from PNG might pose a biosecurity threat to northern Australian tropical cucurbit production should they prove more virulent than those already present. Because of such findings, and the genetic connectivity found between East Timorese and localized northern Australian populations of ZYMV and SPFMV, and between PNG and northern Australian populations of PRSV, Maina et al. (2017a,b, 2018a,c, 2019) highlighted the need to increase biosecurity measures, including viral pathogen surveillance activities, and enhanced preparedness for the containment and eradication of new virus incursions to northern Australia. However, windborne insect virus vectors and migrating birds moving in the opposite direction, along with plants and plant products exported across the sea, might also introduce crop viruses originating in other world regions to PNG or to Australia's Southeast Asian neighbors East Timor and Indonesia. Therefore, this study also highlights the need for enhanced biosecurity measures to protect against potentially damaging crop virus introductions to all countries in this region of the world.

\section{Acknowledgments}

We thank D. Martin for advice about recombination analysis using the RDP5.2 package, and M. P. You of the School of Agriculture and Environment, University of Western Australia, for administrative support.

\section{Literature Cited}

Altschul, S. F., Gish, W., Miller, W., Myers, E. W., and Lipman, D. J. 1990. Basic local alignment search tool. J. Mol. Biol. 215:403-410.

AVA. 2001. Diagnostic records of the Plant Health Diagnostic Services. Online publication. Plant Health Centre, Agri-food and Veterinary Authority, Singapore. https://www.ava.gov.sg/explore-by-sections/plants/plant-health-and-pest-management/ plant-health-services

Bao, Y., Chetvernin, V., and Tatusova, T. 2014. Improvements to pairwise sequence comparison (PASC): A genome-based web tool for virus classification. Arch. Virol. 159:3293-3304.

Blua, M. J., and Perring, T. M. 1989. Effect of zucchini yellow mosaic virus on development and yield of cantaloupe (Cucumis melo). Plant Dis. 73: 317-320.

Boyle, D. B., Amos-Ritchie, R., Broz, I., Walker, P. J., Melville, L., Flanagan, D., Davis, S., Hunt, N., and Weir, R. 2014. Evolution of bluetongue virus serotype 1 in northern Australia over 30 years. J. Virol. 88:13981-13989.

Büchen-Osmond, C., Crabtree, K., Gibbs, A., and Mclean, G. 1988. Viruses of Plants in Australia. Descriptions and Lists from the VIDE Database. Australian National University, Canberra, ACT, Australia.

CABI. 2016. Zucchini yellow mosaic virus. Datasheet No. 57657. Online publication. https://www.cabi.org/isc/datasheet/57657

Castle, S. J., Perring, T. M., Farrar, C. A., and Kishaba, A. N. 1992. Field and laboratory transmission of watermelon mosaic virus 2 and zucchini yellow mosaic virus by various aphid species. Phytopathology 82:235-240.

Chare, E. R., and Holmes, E. C. 2006. A phylogenetic survey of recombination frequency in plant RNA viruses. Arch. Virol. 151:933-946.

Coutts, B. A., and Jones, R. A. C. 2005. Incidence and distribution of viruses infecting cucurbit crops in the Northern Territory and Western Australia. Crop Pasture Sci. 56:847-858.

Coutts, B. A., Kehoe, M. A., and Jones, R. A. C. 2011a. Minimising losses caused by Zucchini yellow mosaic virus in vegetable cucurbit crops in tropical, subtropical and Mediterranean environments through cultural methods and host resistance. Virus Res. 159:141-160.

Coutts, B. A., Kehoe, M. A., and Jones, R. A. C. 2013. Zucchini yellow mosaic virus: Contact transmission, stability on surfaces, and inactivation with disinfectants. Plant Dis. 97:765-771.

Coutts, B. A., Kehoe, M. A., Webster, C. G., Wylie, S. J., and Jones, R. A. C. 2011 b. Zucchini yellow mosaic virus: Biological properties, detection procedures and comparison of coat protein gene sequences. Arch. Virol. 156:2119-2131.

Daryono, B. S., and Natsuaki, K. T. 2016. Survey on the occurrence of viruses infecting cucurbits in Yogyakarta and central Java. Jurnal Perlindungan Tanaman Indonesia (Indones. J. Plant Prot.) 15:2.

Davis, R. I., Thomas, J. E., McMichael, L. A., Dietzgen, R. G., Callaghan, B., James, A. P., Gunua, T. G., and Rahamma, S. 2002. Plant virus surveys on the island of New Guinea and adjacent regions of northern Australia. Australas. Plant Pathol. 31:385-390.

Denham, T. P., Haberle, S. G., Lentfer, C., Fullagar, R., Field, J., Therin, M., Porch, N., and Winsborough, B. 2003. Origins of agriculture at Kuk Swamp in the highlands of New Guinea. Science 301:189-193.
Desbiez, C., and Lecoq, H. 1997. Zucchini yellow mosaic virus. Plant Pathol. 46: 809-829.

Desbiez, C., and Lecoq, H. 2008. Evidence for multiple intraspecific recombinants in natural populations of Watermelon mosaic virus (WMV, Potyvirus). Arch Virol. 153:1749-1754.

Desbiez, C., Wipf-Scheibel, C., and Lecoq, H. 2002. Biological and serological variability, evolution and molecular epidemiology of Zucchini yellow mosaic virus (ZYMV, Potyvirus) with special reference to Caribbean islands. Virus Res. 85:5-16.

Eagles, D., Melville, L. F., Weir, R., Davis, S., Bellis, G., Zalucki, M. P., Walker, P. J., and Durr, P. A. 2014. Long-distance aerial dispersal modeling of Culicoides biting midges: Case studies of incursions into Australia. BMC Vet. Res. 10:135

Eagles, D., Walker, P. J., Zalucki, M. P., and Durr, P. A. 2013. Modelling spatiotemporal patterns of long-distance Culicoides dispersal into northern Australia. Prev. Vet. Med. 110:312-322.

EPPO. 2014. Plant quarantine data retrieval system database. Online publication. European and Mediterranean Plant Protection Organization, Paris, France. https://www.eppo.int/DATABASES/pqr/pqr.htm

Firth, C., Blasdell, K. R., Amos-Ritchie, R., Sendow, I., Agnihotri, K., Boyle, D. B., Daniels, P., Kirkland, P. D., and Walker, P. J. 2017. Genomic analysis of bluetongue virus episystems in Australia and Indonesia. Vet. Res. 48:82.

Fujisawa, I., Anang, S. J., Shen, Y. S., and Zhou, A. J. 1990. Identification of virus diseases affecting some vegetable crops in west Malaysia and the southern part of China. Online publication. Trop. Agric. Res. Ser. No. 23:218-228. http:// agris.fao.org/agris-search/search.do?recordID=JP9204173

Fujisawa, I., Hanada, T., and Anang, S. B. 1986. Virus diseases occurring on some vegetable crops in West Malaysia. Jpn. Agric. Res. Q. 20:78-84.

Gal-On, A. 2007. Zucchini yellow mosaic virus: Insect transmission and pathogenicity-The tails of two proteins. Mol. Plant Pathol. 8:139-150.

Gibbs, A. J., Mackenzie, A. M., Wei, K., and Gibbs, M. J. 2008. The potyviruses of Australia. Arch. Virol. 153:1411-1420.

Gibbs, A. J., and Ohshima, K. 2010. Potyviruses and the digital revolution. Annu Rev. Phytopathol. 48:205-223.

Gibbs, A. J., Ohshima, K., Yasaka, R., Mohammadi, M., Gibbs, M. J., and Jones, R. A. C. 2017. The phylogenetics of the global population of Potato virus $Y$ and its necrogenic recombinants. Virus Evol. 3:vex002.

Gibbs, M. J., Armstrong, J. S., and Gibbs, A. J. 2000. Sister-scanning: A Monte Carlo procedure for assessing signals in recombinant sequences. Bioinformatics 16:573-582.

Greber, R. S., McLean, G. D., and Grice, M. S. 1987. Zucchini yellow mosaic virus in three states of Australia. Australas. Plant Pathol. 16:19-21.

Greber, R. S., Persley, D. M., and Herrington, M. E. 1988. Some characteristics of Australian isolates of zucchini yellow mosaic virus. Aust. J. Agric. Res. 39: 1085-1094

Guerret, M. G. L., Nyalugwe, E. P., Maina, S., Barbetti, M. J., van Leur, A. G. J., and Jones, R. A. C. 2017. Biological and molecular properties of a Turnip mosaic virus (TuMV) strain that breaks TuMV resistances in Brassica napus. Plant Dis. 101:674-683.

Ha, C., Revill, P., Harding, R. M., Vu, M., and Dale, J. L. 2008. Identification and sequence analysis of potyviruses infecting crops in Vietnam. Arch. Virol. 153: $45-60$

Hutterer, K. P. 1983. The natural and cultural history of Southeast Asian agriculture: Ecological and evolutionary considerations. Anthropos 78: 169-212.

James, D., Sanderson, D., Varga, A., Sheveleva, A., and Chirkov, S. 2016 Genome sequence analysis of new isolates of the Winona strain of Plum pox virus and the first definitive evidence of intrastrain recombination events. Phytopathology 106:407-416.

Johansen, C. A., Farrow, R., Morrisen, A., Mackenzie, J. S., and Ritchie, S. A. 2001. Windborne mosquitoes: Could they be a mechanism of incursions of Japanese encephalitis virus into Australia? Arbovirus Res. Aust. 8:180-186.

Johansen, C. A., Farrow, R. A., Morrisen, A., Bellis, G., van den Hurk, A. F., Montgomery, B., Mackenzie, J. S., and Ritchie, S. A. 2003. Collection of wind-borne haematophagous insects in the Torres Strait, Australia. Med. Vet. Entomol. 17:102-111

Jones, R. A. C. 1996. Report on Survey for Virus Diseases in Crops in the Ord River Irrigation Area, 12-14 August 1996. Northern Australian Quarantine Strategy (NAQS). Agriculture Western Australia, Perth, WA, Australia.

Jones, R. A. C. 2009. Plant virus emergence and evolution: Origins, new encounter scenarios, factors driving emergence, effects of changing world conditions, and prospects for control. Virus Res. 141:113-130.

Jones, R. A. C. 2016. Future scenarios for plant virus pathogens as climate change progresses. Adv. Virus Res. 95:87-147.

Jones, R. A. C., and Barbetti, M. J. 2012. Influence of climate change on plant disease infections and epidemics caused by viruses and bacteria. CAB Rev. 7:1-33. https://www.cabdirect.org/cabdirect/abstract/20123205496

Jones, R. A. C., and Kehoe, M. A. 2016. A proposal to rationalize within-species plant virus nomenclature: Benefits and implications of inaction. Arch. Virol. 161:2051-2057.

Karasev, A. V., Hu, X., Brown, C. J., Kerlan, C., Nikolaeva, O. V., Crosslin, J. M., and Gray, S. M. 2011. Genetic diversity of the ordinary strain of Potato virus $Y$ (PVY) and origin of recombinant PVY strains. Phytopathology 101:778-785. 
Katis, N. I., Tsitsipis, J. A., Lykouressis, D. P., Papapanayotou, A., Margaritopoulos, J. T., Kokinis, G. M., Perdikis, D. C., and Manoussopoulos, I. N. 2006. Transmission of Zucchini yellow mosaic virus by colonizing and non-colonizing aphids in Greece and new aphid species vectors of the virus. J. Phytopathol. 154:293-302.

Katoh, K., Misawa, K., Kuma, K.-I., and Miyata, T. 2002. MAFFT: A novel method for rapid multiple sequence alignment based on fast Fourier transform. Nucleic Acids Res. 30:3059-3066.

Kearse, M., Moir, R., Wilson, A., Stones-Havas, S., Cheung, M., Sturrock, S., Buxton, S., Cooper, A., Markowitz, S., Duran, C., Thierer, T., Ashton, B., Meintjes, P., and Drummond, A. 2012. Geneious basic: An integrated and extendable desktop software platform for the organization and analysis of sequence data. Bioinformatics 12:1647-1649. doi:

Kehoe, M. A., Coutts, B. A., Buirchell, B., and Jones, R. A. C. 2014a. Plant virology and next generation sequencing: Experiences with a Potyvirus. PLoS One 9:e104580.

Kehoe, M. A., Coutts, B. A., Buirchell, B., and Jones, R. A. C. 2014b. Split personality of a potyvirus: To specialize or not to specialize. PLoS One 9:e105770.

Kumar, S., Stecher, G., and Tamura, K. 2016. MEGA7: Molecular evolutionary genetics analysis version 7.0 for bigger datasets. Mol. Biol. Evol. 33: 1870-1874.

Lai, M. M. 1992. RNA recombination in animal and plant viruses. Microbiol. Rev. 56:61-79.

Larkin, M. A., Blackshields, G., Brown, N. P., Chenna, R., McGettigan, P. A., McWilliam, H., Valentin, F., Wallace, I. M., Wilm, A., Lopez, R., and Thompson, J. D. 2007. Clustal W and Clustal X version 2.0. Bioinformatics 23:2947-2948.

Lecoq, H., and Desbiez, C. 2008. Watermelon mosaic virus and Zucchini yellow mosaic virus. Encyclopedia Virol. 5:433-440.

Lecoq, H., Desbiez, C., Wipf-Scheibel, C., and Girard, M. 2003. Potential involvement of melon fruit in the long distance dissemination of cucurbit potyviruses. Plant Dis. 87:955-959.

Lecoq, H., and Katis, N. 2014. Control of cucurbit viruses. Adv. Virus Res. 90: 255-296.

Lisa, V., Boccardo, G., D'Agostino, G., Dellavalle, G., and d'Aquilio, M. 1981. Characterization of a potyvirus that causes zucchini yellow mosaic. Phytopathology 71:667-672.

Maina, S., Barbetti, M. J., Edwards, O., de Almeida, L., Ximenes, A., and Jones, R. A. C. 2018a. Sweet potato feathery mottle virus and Sweet potato virus $C$ from East Timorese and Australian sweetpotato: Biological and molecular properties, and biosecurity implications. Plant Dis. 102:589-599.

Maina, S., Barbetti, M. J., Edwards, O. R., Minemba, D., Areke, M. W., and Jones R. A. C. 2019. Genetic connectivity Papaya ringspot virus genomes from Papua New Guinea and northern Australia, and new recombination insights. Plant Dis. In press. doi:10.1094/PDIS-07-18-1136-RE

Maina, S., Barbetti, M. J., Edwards, O. R., Minemba, D., Areke, M. W., and Jones, R. A. C. 2018b. First complete genome sequence of Cucurbit aphid-borne yellows virus from Papua New Guinea. Genome Announce. 6:e0162-18.

Maina, S., Barbetti, M. J., Martin, D. P., Edwards, O. R., and Jones, R. A. C. 2018c. New isolates of Sweet potato feathery mottle virus and Sweet potato virus C: Biological and molecular properties, and recombination analysis based on complete genomes. Plant Dis. 102:1899-1914. doi:

Maina, S., Coutts, B. A., Edwards, O. R., de Almeida, L., Kehoe, M. A., Ximenes, A., and Jones, R. A. C. 2017a. Zucchini yellow mosaic virus populations from East Timorese and northern Australian cucurbit crops: Molecular properties, genetic connectivity and biosecurity implications. Plant Dis. 101:1236-1245.

Maina, S., Coutts, B. A., Edwards, O. R., de Almeida, L., Ximenes, A., and Jones, R. A. C. 2017b. Papaya ringspot virus populations from East Timorese and northern Australian cucurbit crops: Biological and molecular properties, and absence of genetic connectivity. Plant Dis. 101:985-993.

Maina, S., Edwards, O. R., Barbetti, M. J., de Almeida, L., Ximenes, A., and Jones, R. A. C. 2016a. Deep sequencing reveals complete genome of Sweet potato virus $G$ from East Timor. Genome Announce. 4:e00957-16.

Maina, S., Edwards, O. R., de Almeida, L., Ximenes, A., and Jones, R. A. C. 2016b. Complete genome sequences of the Carlavirus Sweet potato chlorotic fleck virus from East Timor and Australia. Genome Announce. 4:e00414-16.

Maina, S., Edwards, O. R., de Almeida, L., Ximenes, A., and Jones, R. A. C. 2016c. Complete genome sequences of the Potyvirus Sweet potato virus 2 from East Timor and Australia. Genome Announce. 4:e00504-16.

Maina, S., Edwards, O. R., de Almeida, L., Ximenes, A., and Jones, R. A. C. 2016d. First complete genome sequence of Suakwa aphid-borne yellows virus from East Timor. Genome Announce. 4:e00718-16.

Maina, S., Edwards, O. R., de Almeida, L., Ximenes, A., and Jones, R. A. C. 2016e. First complete genome sequence of Bean common mosaic necrosis virus from East Timor. Genome Announce. 4:e01049-16.

Maina, S, Edwards, O. R., de Almeida, L., Ximenes, A., and Jones, R. A. C. 2017c. Metagenomic analysis of cucumber RNA from East Timor reveals an Aphid lethal paralysis virus genome. Genome Announce. 5:e01445-16.

Maina, S., Edwards, O. R., de Almeida, L., Ximenes, A., and Jones, R. A. C. 2017d. RNA-seq strand specific library from East Timorese cucumber sample reveals complete Cucurbit aphid-borne yellows virus genome. Genome Announce. 5:e00320-17.

Maina, S., Edwards, O. R., de Almeida, L., Ximenes, A., and Jones, R. A. C. 2017e. First complete Squash leaf curl China virus genomic segment DNAA sequence from East Timor. Genome Announce. 5:e00483-17.
Maina, S., Edwards, O. R., and Jones, R. A. C. 2016f. First complete genome sequence of Pepper vein yellows virus from Australia. Genome Announce. 4:e00450-16.

Maina, S., Edwards, O. R., and Jones, R. A. C. 2017f. Two complete genome sequences of Squash mosaic virus from 20-year-old cucurbit leaf samples from Australia. Genome Announce. 5:e00778-17.

Maina, S., and Jones, R. A. C. 2017. Analysis of an RNA-seq strand-specific library sample reveals a complete genome of Hardenbergia mosaic virus from native wisteria, an indigenous virus from Southwest Australia. Genome Announce. 5:e00599-17.

Martin, D. P., Murrell, B., Golden, M., Khoosal, A., and Muhire, B. 2015. RDP4 Detection and analysis of recombination patterns in virus genomes. Virus Evol. 1:vev003.

Martin, D. P., Posada, D., Crandall, K. A., and Williamson, C. 2005. A modified BOOTSCAN algorithm for automated identification of recombinant sequences and recombination breakpoints. AIDS Res. Hum. Retroviruses 21:98-102.

McGuire, G., and Wright, F. 2000. TOPAL 2.0: Improved detection of mosaic sequences within multiple alignments. Bioinformatics 16:130-134.

Moury, B. 2010. A new lineage sheds light on the evolutionary history of Potato virus Y. Mol. Plant Pathol. 11:161-168.

Muhire, B. M., Varsani, A., and Martin, D. P. 2014. SDT: A virus classification tool based on pairwise sequence alignment and identity calculation. PLoS One 9:e108277.

Ndunguru, J., Taylor, N. J., Yadav, J., Aly, H., Legg, J. P., Aveling, T., Thompson, G., and Fauquet, C. M. 2005. Application of FTA technology for sampling, recovery and molecular characterization of viral pathogens and virus-derived transgenes from plant tissues. Virol. J. 2:45

Ogawa, T., Nakagawa, A., Hataya, T., and Ohshima, K. 2012. The genetic structure of populations of Potato virus $Y$ in Japan; based on the analysis of 20 full genomic sequences. J. Phytopathol. 160:661-673.

Ohshima, K., Tomitaka, Y., Wood, J. T., Minematsu, Y., Kajiyama, H., Tomimura, K., and Gibbs, A. J. 2007. Patterns of recombination in Turnip mosaic virus genomic sequences indicate hotspots of recombination. J. Gen. Virol. 88:298-315.

Ohshima, K., Yamaguchi, Y., Hirota, R., Hamamoto, T., Tomimura, K., Tan, Z., Sano, T., Azuhata, F., Walsh, J. A., Fletcher, J., Chen, J., Gera, A., and Gibbs, A. 2002. Molecular evolution of Turnip mosaic virus: Evidence of host adaptation, genetic recombination and geographical spread. J. Gen. Virol. 83:1511-1521.

Onyango, M. G., Beebe, N. W., Gopurenko, D., Bellis, G., Nicholas, A., Ogugo, M., Djikeng, A., Kemp, S., Walker, P. J., and Duchemin, J. B. 2015. Assessment of population genetic structure in the arbovirus vector midge, Culicoides brevitarsis (Diptera: Ceratopogonidae), using multi-locus DNA microsatellites. Vet. Res. 46:108.

Padidam, M., Sawyer, S., and Fauquet, C. M. 1999. Possible emergence of new geminiviruses by frequent recombination. Virology 265:218-225.

Posada, D., and Crandall, K. A. 2001. Evaluation of methods for detecting recombination from DNA sequences: Computer simulations. Proc. Natl. Acad. Sci. USA 98:13757-13762.

Revers, F., Le Gall, O., Candresse, T., Le Romancer, M., and Dunez, J. 1996. Frequent occurrence of recombinant potyvirus isolates. J. Gen. Virol. 77 1953-1965.

Robinson, R. W., Provvidenti, R., and Shail, J. W. 1993. Tests for seedborne transmission of zucchini yellow mosaic virus. HortScience 28:694-696.

Santillan, F. W., Fribourg, C. E., Adams, I. P., Gibbs, A. J., Boonham, N., Kehoe, M. A., Maina, S., and Jones, R. A. C. 2018. The biology and phylogenetics of Potato virus $S$ isolates from the Andean Region of South America. Plant Dis. 102:869-885

Schrijnwerkers, C. C. F. M., Huijberts, N., and Bos, L. 1991. Zucchini yellow mosaic virus: Two outbreaks in the Netherlands and seed transmissibility. Eur. J. Plant Pathol. 97:187-191

Smith, J. M. 1992. Analyzing the mosaic structure of genes. J. Mol. Evol. 34: 126-129.

Somowiyarjo, S. 1993. Detection and identification of cucurbit viruses in Yogyakarta. Ilmu Pertanian 5:657-663.

Tan, Z., Wada, Y., Chen, J., and Ohshima, K. 2004. Inter- and intra-lineage recombinants are common in natural populations of Turnip mosaic virus. J. Gen. Virol. 85:2683-2696.

Valli, A., Lopez-Moya, J. J., and Garcia, J. A. 2007. Recombination and gene duplication in the evolutionary diversification of P1 proteins in the family Potyviridae. J. Gen. Virol. 88:1016-1028.

Visser, J. C., Bellstedt, D. U., and Pirie, M. D. 2012. The recent recombinan evolution of a major crop pathogen Potato virus Y. PLoS One 7:e50631.

Webster, C. G. 2008. Characterisation of Hardenbergia mosaic virus and development of microarrays for detecting viruses in plants. Ph.D. thesis, Murdoch University.

Wong, S. M., Chng, C. G., Chng, C. Y., and Chong, P. L. 1994. Characterization of an isolate of zucchini yellow mosaic virus from cucumber in Singapore. Phytopathology 141:355-368.

Wong, S. M., Lee, S. C., and Loi, J. S. 1992. First report of zucchini yellow mosaic virus in Singapore. Plant Dis. 76:972.

Yuan, C., and Ullman, D. E. 1996. Comparison of efficiency and propensity as measures of vector importance in zucchini yellow mosaic potyvirus transmission by Aphis gossypii and A. craccivora. Phytopathology 86:698-703.

Zitter, T. A., Hopkins, D. L., and Thomas, C. E., eds. 1996. Compendium of Cucurbit Diseases. Disease Compendium Series. American Phytopathological Society, St. Paul, MN. 